\title{
Mycobiota in Chilean chilli Capsicum annuum L. used for production of Merkén
}

\author{
Jéssica Costa ${ }^{\mathrm{a}}$, Rodrigo Rodríguez ${ }^{\mathrm{b}}$, Carla Santos ${ }^{\mathrm{b}}$, Célia Soares ${ }^{\mathrm{b}}$, Nelson Lima ${ }^{\mathrm{b}}$, Cledir Santos ${ }^{\mathrm{a}, *}$ \\ ${ }^{a}$ Department of Chemical Science and Natural Resources, BIOREN-UFRO, Universidad de La Frontera, 4811-230 Temuco, Chile \\ ${ }^{\mathrm{b}}$ CEB-Centre of Biological Engineering, Micoteca da Universidade do Minho (MUM), University of Minho, Campus de Gualtar, Braga 4710-057, Portugal
}

\section{A R T I C L E I N F O}

\section{Keywords:}

Chilli

Spoilage fungi

Mycotoxigenic fungi

Mycobiota identification

OTA

\begin{abstract}
A B S T R A C T
This work aims to provide the first study on the mycobiota present in Chilean pepper Capsicum annuum L. cv. "Cacho de Cabra" throughout the early production stages. Two hundred and forty berry fruits were sampled: 1) at the ripe fruits harvest day; 2) during drying; and 3) smoking processes. A total of 192 strains, encompassing 11 genera and 44 species, were identified through analysis of $\beta$-tubulin (benA) gene and internal transcribed spacer of ribosomal DNA (ITS) region. All collection points showed samples with high fungal contamination, but the mycobiota composition varied as a result of different environmental conditions. Alternaria spp. and Fusarium spp. were predominantly isolated from fresh fruits of $C$. annuum. Penicillium spp. was the most frequent genus in all analysed points. Penicillium brevicompactum and P. crustosum were the most abundant species. Among Aspergillus, A. niger and A. flavus were dominant after the drying phase. In our study, none of the analysed strains of Penicillium (113) and Aspergillus (35) produced Ochratoxin A at detectable levels. The broad characterization of the fungal community of $C$. annuum carried out in this study, could be a guideline for future mycotoxin analyses performed directly on the pod. Understanding the role and dynamics of mycobiota and its relationship with the toxins present in this substrate, will be useful to establish and improve control measures considering the specificities of each point in the $C$. annuum production chain.
\end{abstract}

\section{Introduction}

Capsicum genus is a horticultural crop produced worldwide. Its exotic flavour, aroma, colour, and pungency popularised Capsicum peppers, making them the second largest consumed spice throughout the world, especially in Asia and Latin America. According to the Food and Agriculture Organisation (FAO), in 2016, the worldwide production area for dried Capsicum was 1,798,847 ha, with a production of $3,918,159 \mathrm{t}$ of harvested product per year (FAOSTAT, 2018).

In Chile, the main species of cultivated pepper is $C$. annuum, which is popularly known as "aji" (Govindarajan and Salzer, 1985). A particular landrace of C. annuum L. cv. "Cacho de Cabra" is the second mostproduced variety in Chilean territory, mainly in the Region of La Araucanía (FIA, 2006).

The production of C. annuum L. cv. "Cacho de Cabra" by small farmers has been carried out predominantly in artisan or semi-industrial forms. In both cases, it begins with the sowing of selected seeds in a nursery, which occurs between May to June (end of autumn to early winter in the Southern Hemisphere). Then, from August to
September (end of winter to early spring), plants are transplanted to the field for plant growth and berry fruit production. Finally, from March to April (beginning of autumn), berry fruits are harvested (FIA, 2006).

After harvest, berry fruits are usually dried by direct sun exposure or mechanical heat. Traditionally, this process takes place inside "Rucas", typical houses made of wood and straw, with berry fruits being placed on the floor and turned several times to obtain an even drying. Artisanal drying can take between 5 and 15 days, depending on the number of available sun hours and weather conditions (FIA, 2010). After drying, berry fruits go through a smoking process for approximately half an hour on a native wood fire. This process generates a product with a specific darker colour and a certain smoky flavour (Costa et al., 2019a).

Capsicum annuum L. cv. "Cacho de Cabra" can be sold whole, fresh, crushed, and mixed with other spices. However, they are predominantly used as raw material to produce a powdered pepper known as Merkén (Costa et al., 2019a). As expected, high-quality of Merkén is directly linked to a selection of high-quality pods (FIA, 2010). However, research on mycobiota, including mycotoxigenic species, was carried out predominantly on chilli powder and other chilli by-products

\footnotetext{
* Corresponding author.

E-mail addresses: j.souza01@ufromail.cl (J. Costa), r.rodriguez09@ufromail.cl (R. Rodríguez), carla.santos@ceb.uminho.pt (C. Santos), celia.soares@ceb.uminho.pt (C. Soares),nelson@ie.uminho.pt (N. Lima), cledir.santos@ufrontera.cl (C. Santos).
} 
(Atanda et al., 1990; Casquete et al., 2017; Ham et al., 2016; RuizMoyano et al., 2009; Santos et al., 2011; Tančinová et al., 2014). To date, few studies have reported the mycobiota of $C$. annuum berry fruits and none has described it in all stages of production (da Cruz Cabral et al., 2016; Frimpong et al., 2019; Haruna et al., 2017).

The agricultural practices used by farmers that produce $C$. annuum L. cv. "Cacho de Cabra" are highly empirical, based on ancestral agriculture practices and do not consider the prevention of fungal growth and further potential contamination with mycotoxins (FIA, 2010). For the Chilean ecotype of $C$. annuum L. cv. "Cacho de Cabra" there is no data on mycobiota diversity.

Origin of the raw material, hygiene conditions, temperature, humidity and water activity $\left(\mathrm{a}_{\mathrm{w}}\right)$ are critical factors to fungal colonization and mycotoxin biosynthesis (Ahn et al., 2010; Almela et al., 2007; Iqbal et al., 2011; Sanchis and Magan, 2004). The Chilean Mycotoxin Surveillance Program reported a contamination of Capsicum samples with Aflatoxins and Ochratoxin A beyond the maximum tolerable limits (MTL) established by the European Commission (Foerster et al., 2020). Ochratoxin A contamination was also reported in Merkén, a derivative product from C. annuum (Agencia Chilena para la Calidad e Inocuidad Alimentaria [ACHIPIA], 2018).

These recent mycotoxin contamination alerts point out that fungal contamination, especially by potentially mycotoxigenic species, should not be underestimated in Chilean Capsicum and its derivatives. However, there is no available data on fungal population loads in $C$. annuum L. cv. "Cacho de Cabra" during the harvesting and post-harvest phases, including drying and smoking processes. For this reason, the objective of the present work is to provide the first study on the mycobiota of Chilean pepper C. annuum L. cv. "Cacho de Cabra" during the initial stages of traditional agricultural cultivation. The strains of Aspergillus and Penicillium isolated will be also analysed as to its ochratoxigenic potential.

\section{Materials and methods}

\subsection{Study area}

Berry fruits samples of Capsicum annuum L. cv. "Cacho de Cabra" were collected in the following rural localities of the Region of La Araucanía, Chile (Fig. 1): Nueva Imperial (S $38^{\circ} 72^{\prime} 07^{\prime \prime}$, W $72^{\circ} 91^{\prime} 19^{\prime \prime}$ ), Hualacura (S $38^{\circ} 71^{\prime} 98^{\prime \prime}$, W $72^{\circ} 94^{\prime} 00^{\prime \prime}$ ), Cholchol (S $38^{\circ} 57^{\prime} 02^{\prime \prime}$, W $72^{\circ}$ $81^{\prime} 96^{\prime \prime}$ ) and Purén (Lumaco) (S $38^{\circ} 16^{\prime} 42^{\prime \prime}$, W $72^{\circ} 82^{\prime} 08^{\prime \prime}$ ).

\subsection{Sampling}

Capsicum annuum L. cv. "Cacho de Cabra" pod samples were provided by 8 farmers from Nueva Imperial (2), Hualacura (1), Cholchol (1) and Purén (Lumaco) (4). Samples were collected from April to June 2017 at 3 different sampling points: 1 ) at the ripe fruits harvest day (SP I); 2) during the drying process (1 month after harvest, SP II); and 3) during the smoking process (SP III). For each sampling point, 10 chilli pods were obtained from each farmer, totalling 240 samples collected and analysed (SP I, $n=80$; SP II, $n=80$; SP III, $n=80$ ). The bulk samples were stored in paper bags, transported in a refrigerated box to the laboratory and processed in the same day.

Average temperature and humidity during SP I sampling were: (April 2017) $12.5{ }^{\circ} \mathrm{C}$ and $87.28 \%$ for Nueva Imperial and Hualacura; $12.1{ }^{\circ} \mathrm{C}$ and $85.61 \%$ for Cholchol, and $12.1{ }^{\circ} \mathrm{C}$ and $85.53 \%$ for Purén (Lumaco). During SP II sampling average temperatures and humidity were: (May 2017): $6.6{ }^{\circ} \mathrm{C}$ and $90.75 \%$ for Nueva Imperial and Hualacura; $8.2{ }^{\circ} \mathrm{C}$ and $89.76 \%$ for Cholchol, and $7.8{ }^{\circ} \mathrm{C}$ and $90.93 \%$ for Purén (Lumaco); while during SP III average temperatures and humidity were: (June 2017) $7.9{ }^{\circ} \mathrm{C}$ and $91.38 \%$ for Nueva Imperial and Hualacura; $7.4{ }^{\circ} \mathrm{C}$ and $91 \%$ for Cholchol, and $6.8{ }^{\circ} \mathrm{C}$ and $93.2 \%$ for Purén (Lumaco) (Meteochile, 2020).

\subsection{Mycological analysis of Capsicum annuum}

In order to isolate the mycobiota, each of the 240 chilli pods was divided into three sections (top, middle, and bottom). A fragment of each section was cut $(1 \times 1 \mathrm{~cm})$ and plated on Malt Extract Agar (MEA, malt extract $20 \mathrm{~g} \mathrm{~L}^{-1}$, mycological peptone $1 \mathrm{~g} \mathrm{~L}^{-1}$, agar $20 \mathrm{~g} \mathrm{~L}^{-1}$, glucose $20 \mathrm{~g} \mathrm{~L}^{-1}$ ), Dichloran Rose Bengal Chloramphenicol agar (DRBC, $\mathrm{KH}_{2} \mathrm{PO}_{4} 1 \mathrm{~g} \mathrm{~L}^{-1}, \mathrm{MgSO}_{4} \cdot 7 \mathrm{H}_{2} \mathrm{O} 0.5 \mathrm{~g} \mathrm{~L}^{-1}$, peptone $5 \mathrm{~g} \mathrm{~L}^{-1}$, dichloran $0.002 \mathrm{~g} \mathrm{~L}^{-1}$, chloramphenicol $0.1 \mathrm{~g} \mathrm{~L}^{-1}$, agar $15 \mathrm{~g} \mathrm{~L}^{-1}$, glucose $10 \mathrm{~g} \mathrm{~L}^{-1}$, rose bengal $0.025 \mathrm{~g} \mathrm{~L}^{-1}$ ) and Dichloran $18 \%$ Glycerol Agar (DG18, mycological peptone $5 \mathrm{~g} \mathrm{~L}^{-1}$, glucose $10 \mathrm{~g} \mathrm{~L}^{-1} ; \mathrm{KH}_{2} \mathrm{PO}_{4}$ $1 \mathrm{~g} \mathrm{~L}^{-1}, \mathrm{MgSO}_{4} \cdot 7 \mathrm{H}_{2} \mathrm{O} 0.5 \mathrm{~g} \mathrm{~L}^{-1}$, glycerol $220 \mathrm{~g} \mathrm{~L}^{-1}$, dichloran $0.002 \mathrm{~g} \mathrm{~L}^{-1}$, chloramphenicol $0.1 \mathrm{~g} \mathrm{~L}^{-1}$, agar $15 \mathrm{~g} \mathrm{~L}^{-1}$ ) medium. Each plate was incubated for 7 days in the dark at $25^{\circ} \mathrm{C}$. Fungal isolates were selected eliminating the fast growing Mucorales giving preference to potentially mycotoxigenic genera.

\subsection{Morphological identification}

For fungal morphological identification, all strains were subcultured on MEA and Potato Dextrose Agar (PDA, $200 \mathrm{~g}$ of infusion from potatoes, glucose $20 \mathrm{~g}$, agar $15 \mathrm{~g}$ ) at $25{ }^{\circ} \mathrm{C}$ for 7 days in the dark. Fungal strains were identified at genus level based on macro- and micro-morphological traits with appropriate keys (Klich, 2002; Nelson et al., 1983; Samson et al., 2000). All fungal strains isolated in the present study (Supplementary Table 1) were deposited at the Chilean Culture Collection of Type Strains (CCCT/UFRO, http://ccct.ufro.cl/), which is member of the World Federation of Culture Collection under the registration number WDCM 1111.

\subsection{Molecular biology analyses}

\subsubsection{Genomic DNA extraction}

Genomic DNA of each isolate was extracted using a modified protocol described by Rodrigues et al. (2009). Briefly, spores of each strain were transferred from a 7 days old culture into $50 \mathrm{~mL}$ tubes containing $25 \mathrm{~mL}$ of Malt Extract-Glucose-Yeast-Peptone Medium (MGYP, malt extract $3 \mathrm{~g} \mathrm{~L}^{-1}$, glucose $10 \mathrm{~g} \mathrm{~L}^{-1}$, yeast extract $3 \mathrm{~g} \mathrm{~L}^{-1}$, peptone $5 \mathrm{~g} \mathrm{~L}^{-1}$ ). Samples were incubated at room temperature for 5 days in the dark, at $150 \mathrm{rpm}$ in a shaker. Fungal biomass was filtrated and stored at $-20{ }^{\circ} \mathrm{C}$.

For DNA extraction, $100 \mathrm{mg}$ of biomass were transferred into a $1.5 \mathrm{~mL}$ micro-tube containing $100 \mu \mathrm{L}$ of lysis buffer (200 mM Tris- $\mathrm{HCl}$ pH 8.5, $250 \mathrm{mM} \mathrm{NaCl}, 25 \mathrm{mM}$ EDTA, 0.5\% ( $w / v)$ SDS). Cell lysis was performed using a pellet pestle for 3-4 min. After mechanical lysis, $900 \mu \mathrm{L}$ of lysis buffer was added and the samples were incubated for $1 \mathrm{~h}$ at $65{ }^{\circ} \mathrm{C}$. Samples were centrifuged at $14,000 \times g$ for $10 \mathrm{~min}$ at room temperature and $800 \mu \mathrm{L}$ of the upper phase was transferred into a new $2 \mathrm{~mL}$ micro-tube.

Polysaccharides and proteins were precipitated by adding $1 \mathrm{~mL}$ of cold sodium acetate ( $3 \mathrm{M}, \mathrm{pH}$ 5.5). Samples were gently mixed by inversion, placed at $-20{ }^{\circ} \mathrm{C}$ for $10 \mathrm{~min}$ and centrifuged at $14,000 \times \mathrm{g}$ for $10 \mathrm{~min}$ at room temperature. Clean supernatant was then transferred into a new micro-tube and precipitated with one volume of cold isopropanol $\left(-20^{\circ} \mathrm{C}\right)$. Samples were gently mixed by inversion for $2 \mathrm{~min}$, incubated at $-20{ }^{\circ} \mathrm{C}$ for $2 \mathrm{~h}$ and centrifuged at $14,000 \times g$ for $10 \mathrm{~min}$.

DNA pellets were washed twice with $1 \mathrm{~mL}$ of cold $70 \%$ ethanol, centrifuged at $14,000 \times g$ for 10 min and dried using a Savant ${ }^{\mathrm{TM}}$ SPD111 SpeedVac Concentrator (Thermo Fisher Scientific Inc., Wilmington, USA). DNA samples were suspended on $50 \mu \mathrm{L}$ of ultra-pure water and stored at $-20{ }^{\circ} \mathrm{C}$. DNA samples were subjected to quality assessment by quantification of total DNA using NanoDrop ${ }^{\mathrm{TM}} 1000$ instrument (Thermo Fisher Scientific Inc., Wilmington, USA) and by electrophoresis agarose gel $1 \%(w / v)$ for $45 \mathrm{~min}$ at $80 \mathrm{~V}$. SYBR ${ }^{\circledast}$ Safe DNA Gel Stain (Invitrogen, Carlsbad, USA) was used as staining element and NZYDNA ladder III (NZYTech Lda, Lisbon, Portugal) was used as DNA molecular 


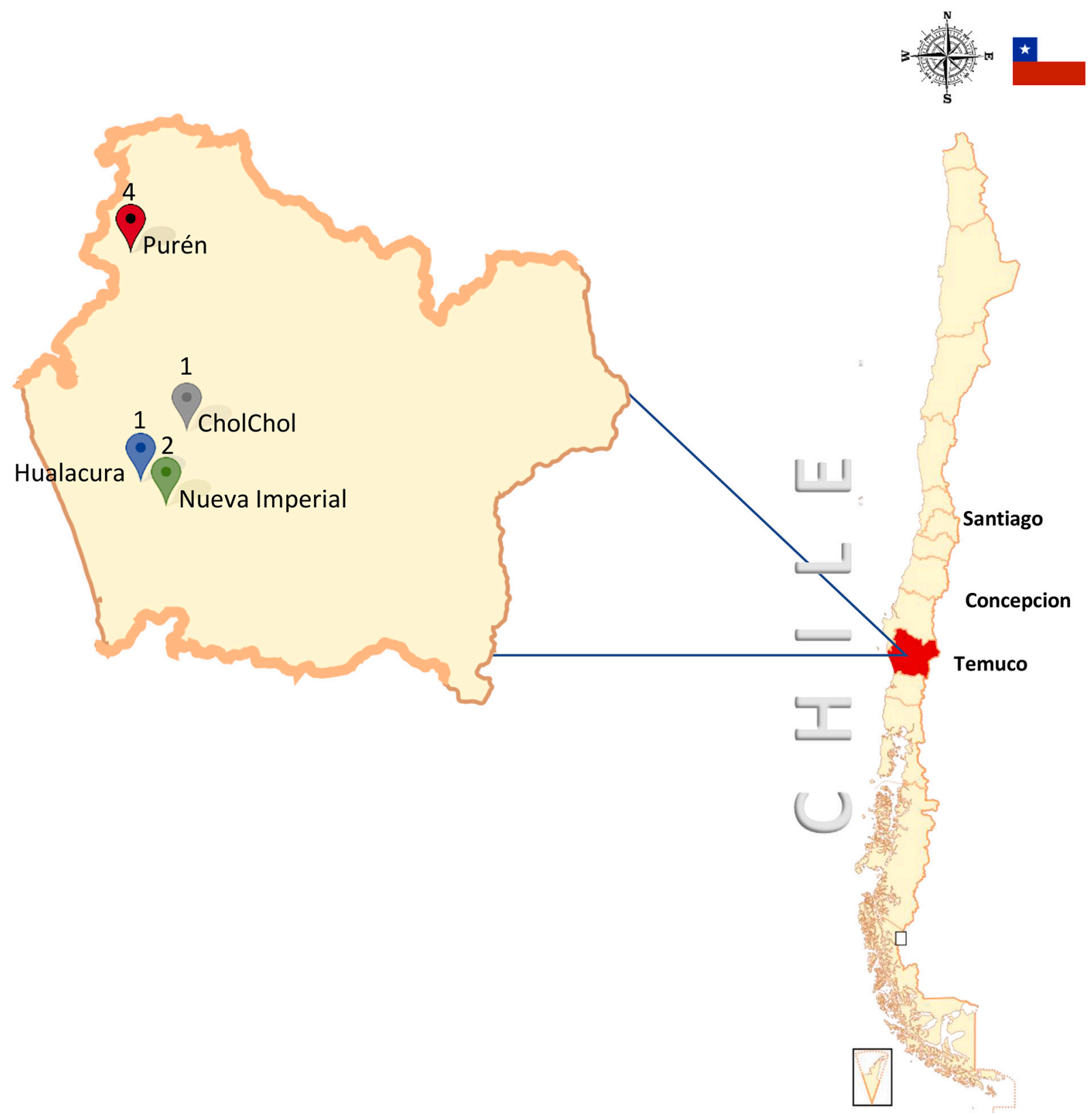

Fig. 1. Location of the sampling localities in the region of La Aracaunía, Chile. Numbers above the location pins indicate the number of Farmers that provided chilli samples.

weight marker.

\subsubsection{PCR amplification}

In order to identify the fungal strains, partial amplification of internal transcribed spacer of ribosomal DNA (ITS) region or $\beta$-tubulin gene (benA) were performed. ITS is regarded as the universal barcode for fungal identification (Schoch et al., 2012) but for specific genera such as Penicillium and Aspergillus benA is a more informative primary barcode when trying to achieve species-level identification (Samson et al., 2014; Visagie et al., 2014). ITS was amplified using primers ITS1 ( $5^{\prime}$-TCC GTA GGT GAA CCT GCG G-3') and ITS4 (5'-TCC TCC GCT TAT TGA TAT GCC-3') design by White et al. (1990). BenA was amplified using primers Bt2a (5'-GGT AAC CAA ATC GGT GCT GCT TTC-3') and Bt2b (5'-ACC CTC AGT GTA GTG ACC CTT GGC-3') design by Glass and Donaldson (1995).

For both regions, PCR reactions included $25 \mu \mathrm{L}$ Taq DNA polymerase Master Mix $2 \times$ (VWR Life Science, Leuven, Belgium), $2 \mu \mathrm{L}$ of each primer at $10 \mathrm{mM}$ and $2 \mu \mathrm{L}$ of total DNA in a final volume of $50 \mu \mathrm{L}$. PCR parameters used in the thermal cycler for ITS were: $94^{\circ} \mathrm{C}$ for $3 \mathrm{~min}$, 35 cycles of $94^{\circ} \mathrm{C}$ for $1 \mathrm{~min}, 55^{\circ} \mathrm{C}$ for $1 \mathrm{~min}, 72^{\circ} \mathrm{C}$ for $1 \mathrm{~min}$ and a final extension at $72{ }^{\circ} \mathrm{C}$ for $5 \mathrm{~min}$; for ben $A$ were: $95^{\circ} \mathrm{C}$ for $3 \mathrm{~min}, 35$ cycles of $95{ }^{\circ} \mathrm{C}$ for $1 \mathrm{~min}, 56{ }^{\circ} \mathrm{C}$ for $45 \mathrm{~s}, 72{ }^{\circ} \mathrm{C}$ for $90 \mathrm{~s}$ and a final extension at $72{ }^{\circ} \mathrm{C}$ for $10 \mathrm{~min}$.

Amplification success was verified on $1 \%(w / v)$ agarose gels and PCR products purified using NZYGelpure kit (NZYTech Lda, Lisbon, Portugal) according to the manufacturer's instructions and sent to Sanger sequencing to StabVida (Madan Parque, Caparica, Portugal). All sequences were submitted to GenBank and accession codes can be found in Supplementary Table 1.

\subsubsection{Phylogenetic analyses}

Each sequence was compared with the GenBank database using the Basic Local Alignment Search Tool (BLAST, https://blast.ncbi.nlm.nih. gov/). Phylogenetic analyses were performed by comparing sample 
Table 1

Reference strains used for phylogenetic analysis of the study isolates. GenBank accession numbers of ITS and benA sequences used to construct phylogenetic trees are listed here.

\begin{tabular}{|c|c|c|c|c|c|}
\hline \multirow[t]{2}{*}{ Genus } & \multirow[t]{2}{*}{ Species } & \multirow[t]{2}{*}{ Section/species complex/clade } & \multirow[t]{2}{*}{ Strain $^{\mathrm{a}}$} & \multicolumn{2}{|c|}{ GenBank accession numbers } \\
\hline & & & & ITS & benA \\
\hline \multirow[t]{10}{*}{ Alternaria } & alternata & Section Alternaria & CBS $916.96^{\mathrm{T}}$ & AF347031 & - \\
\hline & arborescens & Section Alternaria & CBS $102605^{\mathrm{T}}$ & NR_135927 & - \\
\hline & atra & Section Ulocladioides & ATCC $18040^{\mathrm{T}}$ & AF229486 & - \\
\hline & consortialis & Section Ulocladioides & CBS $104.31^{\mathrm{T}}$ & KC584247 & - \\
\hline & cucurbitae & Section Ulocladioides & CBS $483.81^{R}$ & FJ266483 & - \\
\hline & limoniasperae & Section Alternaria & CBS $102595^{\mathrm{T}}$ & FJ266476 & - \\
\hline & longipes & Section Alternaria & CBS $540.94^{\mathrm{R}}$ & AY278835 & - \\
\hline & multiformis & Section Ulocladioides & CBS $102060^{\mathrm{T}}$ & NR_077187 & - \\
\hline & tenuissima & Section Alternaria & CBS $918.96^{\mathrm{R}}$ & AF347032 & - \\
\hline & terricola & Section Ulocladioides & CBS $202.67^{\mathrm{T}}$ & NR_103600 & - \\
\hline \multirow[t]{8}{*}{ Aspergillus } & brasiliensis & Section Nigri & CBS $101740^{\mathrm{T}}$ & - & FJ629272 \\
\hline & dimorphicus & Section Cremei & CBS $649.74^{\mathrm{T}}$ & - & EF652111 \\
\hline & flavus & Section Flavi & CBS $100927^{\mathrm{T}}$ & - & EF661485 \\
\hline & fumigatus & Section Fumigati & CBS $133.61^{\mathrm{T}}$ & - & EF669791 \\
\hline & luchuensis & Section Nigri & CBS $205.80^{\mathrm{T}}$ & - & JX500062 \\
\hline & niger & Section Nigri & CBS $554.65^{\mathrm{T}}$ & - & EF661089 \\
\hline & pseudoglaucus & Section Aspergillus & CBS $123.28^{\mathrm{T}}$ & - & EF651917 \\
\hline & versicolor & Section Versicolores & CBS $583.65^{\mathrm{T}}$ & - & EF652266 \\
\hline \multirow[t]{3}{*}{ Cephalotrichum } & cylindricum & - & UAMH $1348^{\mathrm{T}}$ & NR_146264 & - \\
\hline & gorgonifer & - & CBS 120011 & KY249257 & - \\
\hline & telluricum & - & CBS $336.32^{\mathrm{T}}$ & NR_154845 & - \\
\hline \multirow[t]{4}{*}{ Cladosporium } & cladosporioides & Cladosporium cladosporioides species complex & CBS $112388^{\mathrm{T}}$ & NR_119839 & - \\
\hline & colocasiae & Cladosporium cladosporioides species complex & CBS $386.64^{\mathrm{T}}$ & NR_119840 & - \\
\hline & oxysporum & Cladosporium cladosporioides species complex & CPC $14371^{\mathrm{T}}$ & NR_152267 & - \\
\hline & westerdijkiae & Cladosporium cladosporioides species complex & CBS $113746^{\mathrm{T}}$ & HM148061 & - \\
\hline \multirow[t]{4}{*}{ Colletorichum } & coccodes & No clade assigned & CBS $369.75^{\mathrm{T}}$ & NR_119858 & - \\
\hline & destructivum & Destructivum clade & CBS $136228^{\mathrm{T}}$ & NR_152280 & - \\
\hline & graminicola & Graminicola clade & CBS $130836^{\mathrm{T}}$ & NR_111190 & - \\
\hline & spaethianum & Spaethianum clade & CBS $167.49^{\mathrm{T}}$ & NR_111451 & - \\
\hline Fusarium & equiseti & Fusarium incarnatum-equiseti species complex & NRRL $26419^{\mathrm{T}}$ & NR_121457 & - \\
\hline & equiseti & Fusarium incarnatum-equiseti species complex & BCCM/IHEM 2823 & KJ125696 & - \\
\hline & equiseti & Fusarium incarnatum-equiseti species complex & BCCM/IHEM 19268 & KJ125578 & - \\
\hline & equiseti & Fusarium incarnatum-equiseti species complex & BCCM/IHEM 19306 & KJ125566 & - \\
\hline & incarnatum & Fusarium incarnatum-equiseti species complex & BCCM/IHEM 20883 & KJ125579 & - \\
\hline & incarnatum & Fusarium incarnatum-equiseti species complex & BCCM/IHEM 18176 & KJ125577 & - \\
\hline & incarnatum & Fusarium incarnatum-equiseti species complex & BCCM/IHEM 1487 & KJ125573 & - \\
\hline & oxysporum & Fusarium oxysporum species complex & BCCM/IHEM 25665 & KJ125664 & - \\
\hline & oxysporum & Fusarium oxysporum species complex & BCCM/IHEM 1243 & KJ125597 & - \\
\hline & redolens & - & NRRL 22901 & U34565 & - \\
\hline Microascus & cinereus & - & UTHSC $10-2805^{\mathrm{T}}$ & NR_132939 & - \\
\hline & gracilis & - & CBS $369.70^{\mathrm{T}}$ & NR_165206 & - \\
\hline Penicillium & adametzioides & Section Sclerotiora & CBS $313.59^{\mathrm{T}}$ & - & JN799642 \\
\hline & angulare & Section Sclerotiora & CBS $130293^{\mathrm{T}}$ & - & KC773779 \\
\hline & bialowiezense & Section Brevicompacta & CBS $227.28^{\mathrm{T}}$ & - & AY674439 \\
\hline & brasilianum & Section Lanata-Diviricata & CBS $253.55^{\mathrm{T}}$ & - & GU981629 \\
\hline & brevicompactum & Section Brevicompacta & CBS $257.29^{\mathrm{T}}$ & - & AY674437 \\
\hline & buchwaldii & Section Brevicompacta & CBS $117181^{\mathrm{T}}$ & - & JX313182 \\
\hline & bussumense & Section Aspergilloides & CBS $138160^{\mathrm{T}}$ & - & KM088685 \\
\hline & chrysogenum & Section Chrysogena & CBS $306.48^{\mathrm{T}}$ & - & AY495981 \\
\hline & citrinum & Section Citrina & CBS $139.45^{\mathrm{T}}$ & - & GU944545 \\
\hline & corylophilum & Section Exilicaulis & CBS $312.48^{\mathrm{T}}$ & - & JX141042 \\
\hline & crustosum & Section Fasciculata & CBS $115503^{\mathrm{T}}$ & - & AY674353 \\
\hline & cyclopium & Section Fasciculata & CBS $144.45^{\mathrm{T}}$ & - & AY674310 \\
\hline & discolor & Section Fasciculata & CBS $474.84^{\mathrm{T}}$ & - & AY674348 \\
\hline & expansum & Section Penicillium & CBS $325.48^{\mathrm{T}}$ & - & AY 674400 \\
\hline & freii & Section Fasciculata & CBS $476.84^{\mathrm{T}}$ & - & AY674290 \\
\hline & frequentans & Section Aspergilloides & CBS $105.11^{\mathrm{T}}$ & - & KM088762 \\
\hline & glabrum & Section Aspergilloides & CBS $125543^{\mathrm{T}}$ & - & GU981619 \\
\hline & melanoconidium & Section Fasciculata & CBS $115506^{\mathrm{T}}$ & - & AY674304 \\
\hline & neoechinulatum & Section Fasciculata & CBS $169.87^{\mathrm{T}}$ & - & AF003237 \\
\hline & paraherquei & Section Lanata-Diviricata & CBS $338.59^{\mathrm{T}}$ & - & KF296465 \\
\hline & polonicum & Section Fasciculata & CBS $222.28^{\mathrm{T}}$ & - & AY674305 \\
\hline & sizovae & Section Citrina & CBS $413.69^{\mathrm{T}}$ & - & GU944535 \\
\hline & verrucosum & Section Fasciculata & CBS $603.74^{\mathrm{T}}$ & - & AY674323 \\
\hline & viridicatum & Section Fasciculata & CBS $390.48^{\mathrm{T}}$ & - & AY674295 \\
\hline Stagonosporopsis & dorenboschii & - & CBS $426.90^{\mathrm{T}}$ & NR_135996 & - \\
\hline & hortensis & - & CBS $104.42^{\mathrm{R}}$ & GU237730 & \\
\hline & loticola & - & CBS $562.81^{\mathrm{T}}$ & NR_163680 & - \\
\hline Talaromyces & pinophilus & Section Talaromyces & CBS $631.66^{\mathrm{T}}$ & - & JX091381 \\
\hline Trichocoma & paradoxa & - & CBS 788.83 & JN899398 & KF984556 \\
\hline
\end{tabular}


Table 1 (continued)

\begin{tabular}{|c|c|c|c|c|c|}
\hline \multirow[t]{2}{*}{ Genus } & \multirow[t]{2}{*}{ Species } & \multirow[t]{2}{*}{ Section/species complex/clade } & \multirow[t]{2}{*}{ Strain $^{\mathrm{a}}$} & \multicolumn{2}{|c|}{ GenBank accession numbers } \\
\hline & & & & ITS & benA \\
\hline \multirow[t]{4}{*}{ Trichoderma } & gamsii & Viride clade & FMR 12636 & NR_131317 & - \\
\hline & koningiopsis & Viride clade & CBS $119075^{\mathrm{T}}$ & NR_131281 & - \\
\hline & trixiae & Viride clade & CBS $134702^{\mathrm{T}}$ & NR_138444 & - \\
\hline & viridescens & Viride clade & CBS 433.34 & NR_138429 & - \\
\hline
\end{tabular}

${ }^{\mathrm{a}} \mathrm{T}$ - type strain; $\mathrm{R}$ - reference strain.

sequences against those of reference species retrieved from the NCBI database (Table 1). Alignment was performed using MUSCLE (Robert, 2004) followed by visual inspection and manual correction using MEGA 7.0 (Kumar et al., 2016).

Maximum likelihood trees based on the most suitable substitution model (determined based on the lowest Bayesian information criterion, varying between Kimura 2-parameter (Kimura, 1980) or Tamura-Nei (Tamura and Nei, 1993) methods and 1000 bootstrap replicates were constructed using MEGA 7.0. All positions containing gaps and missing data were eliminated.

\subsubsection{Diversity analyses}

Shannon-Wiener $\left(H^{\prime}\right)$, Simpson's diversity $\left(D_{1}\right)$, Simpson's dominance $\left(D_{2}\right)$, species richness $(S)$ and Simpson's evenness (E) diversity indices (Shannon, 1948; Simpson, 1949; McCune and Grace, 2002; Whittaker, 1972) were estimated based on species counts for the complete dataset. Species and genus relative abundances were estimated and plotted in $\mathrm{R}$ environment 3.5.1 and RStudio 1.1.383 (RStudio, 2016; R environment, 2020) using vegan package (Oksanen et al., 2018) to estimate Bray-Curtis similarity matrices and pheatmap package (Kolde, 2018) to plot the similarity data using UPGMA clustering method. Species distribution per sampling point was also represented in a Venn diagram generated using VennDiagram package (Chen, 2018) in Rstudio.

For benA and ITS separately, Jukes-Cantor distance matrices between sequences were calculated using MEGA 7.0. Those were used to assign sequences to operational taxonomic units (OTUs), and construct observed and Chaol estimated rarefaction curves using DOTUR furthest neighbour clustering method (Schloss and Handelsman, 2005). For each OTU, a consensus sequence that represented that cluster was derived using Geneious Prime 2020.0.5 (https://www.geneious.com) and subsequently used for phylogenetic analysis as described above.

\subsection{Determination of mycotoxigenic strains}

All Aspergillus and Penicillium strains were tested for OTA production in an inducing Yeast Extract Sucrose agar medium (YES, yeast extract $20 \mathrm{~g} \mathrm{~L}^{-1}$; sucrose $150 \mathrm{~g} \mathrm{~L}^{-1}$; agar $15 \mathrm{~g} \mathrm{~L}^{-1}$; $\mathrm{MgSO}_{4} \cdot 7 \mathrm{H}_{2} \mathrm{O} 0.5 \%$; $\mathrm{ZnSO}_{4} \cdot 7 \mathrm{H}_{2} \mathrm{O} 0.01 \%$; $\mathrm{CuSO}_{4} \cdot 5 \mathrm{H}_{2} \mathrm{O} 0.005 \%$ ) and incubated at $25{ }^{\circ} \mathrm{C}$ for 7 days in the dark (Frisvad and Filtenborg, 1983; Esteban et al., 2006).

For OTA extraction, $2 \mathrm{~mL}$ of methanol were added to 3 agar plugs removed from one colony. After $1 \mathrm{~h}$, the extract was filtered through $0.2 \mu \mathrm{m}$ filters (Bragulat et al., 2001). OTA quantification was performed according to Abrunhosa et al. (2014) using High Performance Liquid Chromatography (Waters, Milford, MA, USA) with a reverse-phase C18 silica gel column $(250 \times 4.6 \mathrm{~mm}, 5 \mu \mathrm{m})$, equipped with a Varian 9002 pump (Agilent, Palo Alto, CA, USA), a Varian Prostar 410 autosampler and Jasco FP-920 fluorescence detector (Jasco Europe, Cremella, Italy). Excitation and emission wavelengths were set at 333 and $460 \mathrm{~nm}$, respectively.

An isocratic mobile phase of acetonitrile/water/acetic acid (99:99:2, $v / v / v)$ was used with a flow rate of $1.0 \mathrm{~mL} \mathrm{~min}^{-1}$. OTA was identified by comparison of the peak samples' retention time with that of the standards. Standards were prepared by serially diluting a primary OTA stock solution $(25 \mu \mathrm{g} / \mathrm{mL})$ supplied by Sigma (O1877). OTA determination in samples was based on the external standard calibration method, using an OTA concentration range of $0.05-100 \mathrm{ppb}$. The calibration curve was $y=1075.8 x+736.3$ and $R 2=0.9972$. Limit of detection (LOD) and limit of quantification (LOQ) were calculated according to the following equations (Taverniers et al., 2004): $\mathrm{LOD}=3.3 \times(\mathrm{sd} / \mathrm{b})$ and LOQ $=10 \times(\mathrm{sd} / \mathrm{b})$, where sd is the standard deviation of the intercept of the regression line obtained from the calibration curve, and $\mathrm{b}$ is the slope of the line. LOD and LOQ were calculated as 7.6 and $23 \mathrm{ppb}$, respectively.

\section{Results and discussion}

\subsection{Mycobiota isolation and identification}

In our study, a total of 192 filamentous fungi strains were isolated and identified from $C$. annuum berry fruits. Of those, 149 were sequenced using benA and 43 using ITS (Supplementary Table 1). Their phylogenetic analysis revealed that the total data set includes 11 genera and 44 different fungal species (Supplementary Figs. 1-3). Predominant genera were Penicillium (58.9\%), Aspergillus (18.2\%), Alternaria (8.9\%) and Fusarium (7.3\%). On the other hand, Cephalotrichum, Cladosporium Colletotrichum, Microascus, Stagonosporopsis, Talaromyces, and Trichoderma were isolated in low frequencies, collectively corresponding to $6.7 \%$ (Fig. 2).

Species belonging to each genus were differently distributed between sampling points (Figs. 3 and 4). Fusarium and Alternaria species are usually isolated from living plants and fresh fruits. Overall, these genera are well adapted to field phase (Sanzani et al., 2016). This was also observed in the present study, with Fusarium spp. being present only in SP I, while Alternaria spp. was isolated in all sampling points, being predominant in SP I and SP II (Figs. 3 and 4). In particular, $F$. incarnatum-equiseti species complex and Alternaria sect. Alternaria were

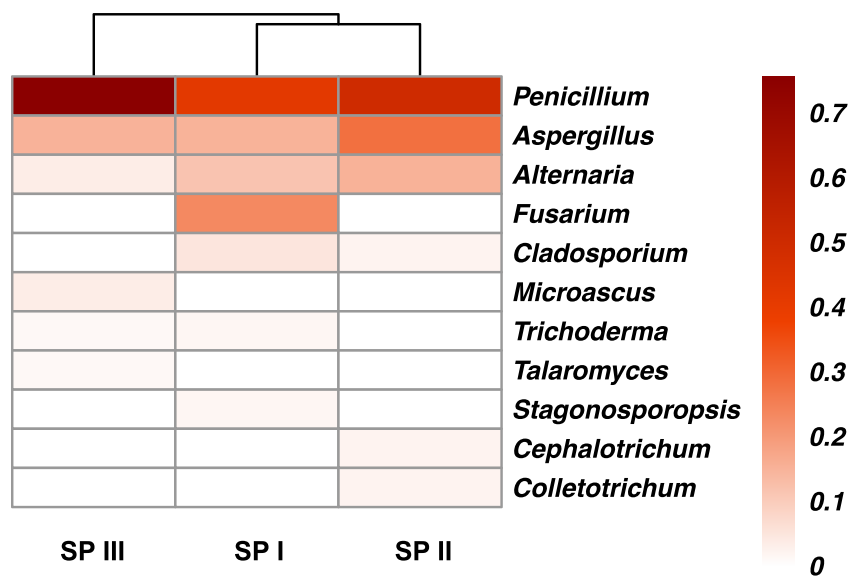

Fig. 2. Heat map showing genus relative abundance distributed by the three sampling points considered (SP I, SP II and SP III). Sites were clustered using UPGMA dendogram based on Bray-Curtis similarities. Colour legend and scale provided in the figure. (For interpretation of the references to colour in this figure legend, the reader is referred to the web version of this article.) 


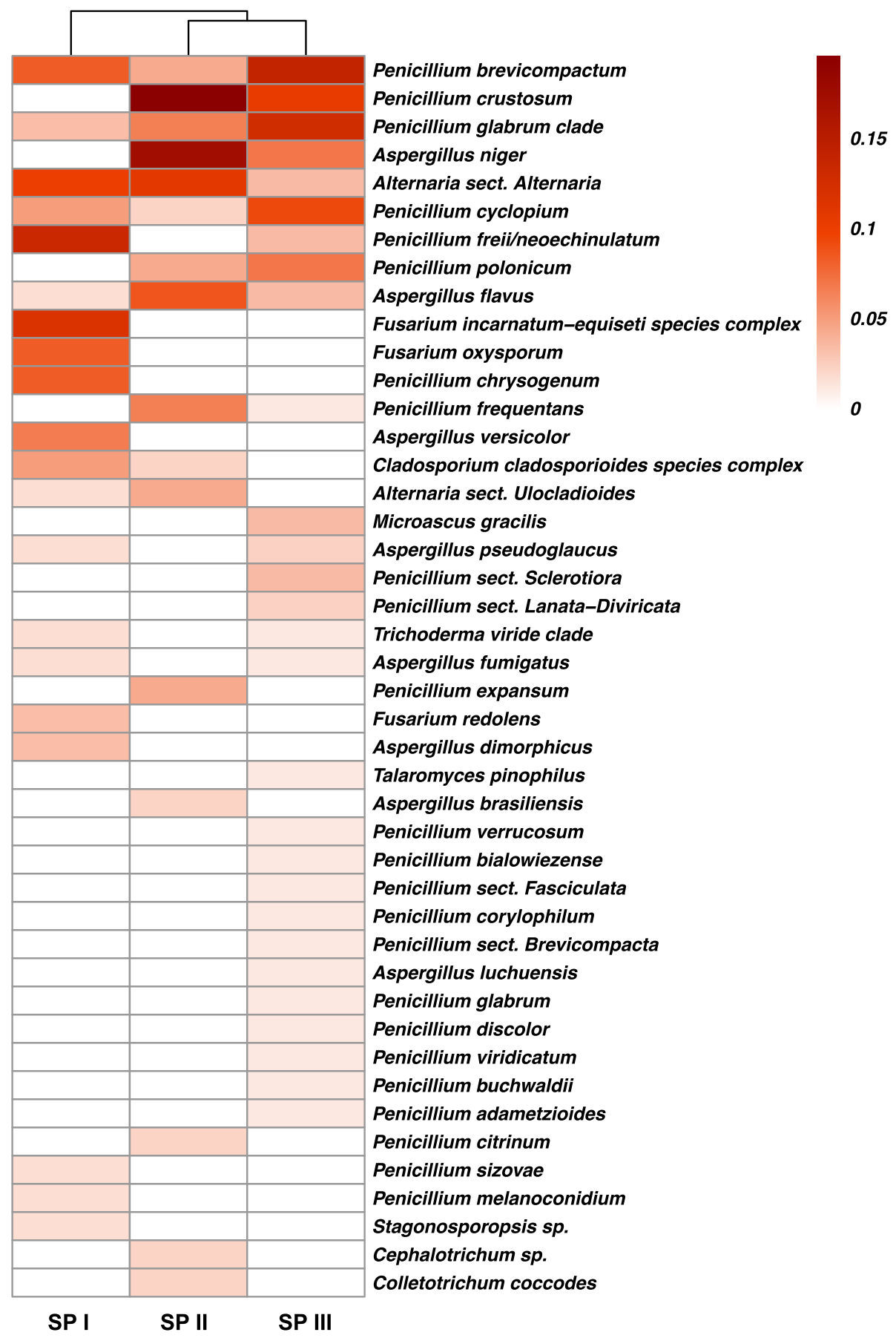

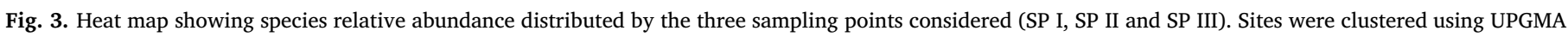

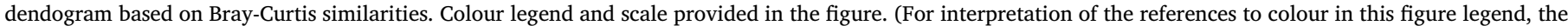
reader is referred to the web version of this article.)

the most prevalent in our study (Fig. 3). Adebanjo and Shopeju (1993) showed that $F$. equiseti was the main species found in fresh fruit of $C$. annuum. Similarly, in the post-harvest phases (SP II and III) of the present study it was observed that the incidence of both Alternaria spp. and Fusarium spp. were low. In fact, in stored samples the predominance of field fungi is switched to xerophilic fungi such as Aspergillus and Penicillium (Fig. 2). Exceptions to this trend include species such as $A$. dimorphicus, $A$. versicolor and $P$. sizovae, which are commonly regarded as saprophytes, soil-borne and opportunistic plant pathogens together with $F$ oxysporum, $F$. redolens and Stagonosporopsis sp. (Houbraken et al., 2010; Garampalli et al., 2016; Haapalainen et al., 2016). These were isolated exclusively from samples of ripe chilli fruits
(SP I, Figs. 3 and 4). Surprisingly, the xerophilic species of A. pseudoglaucus was also isolated from fresh fruit (Fig. 4). This species is generally related to the deterioration of dry foods such as chilli powder (Garcia et al., 2018).

Regarding Penicillium, species from this genus are usually isolated from chilli by-products such as paprika, red pepper flakes and crushed chilli (Santos et al., 2011; Heperkan and Ermis, 2004, Tančinová et al., 2014; Gherbawy et al., 2015; Garcia et al., 2018). As far as we know, this is the first report of $P$. crustosum spoiling pepper fruits at the postharvest stage (SP II and III, Figs. 3 and 4), re-enforcing the idea that this species can be an emerging pathogen. Here, P. crustosum was isolated from chilli pods, usually being reported in cheese, nuts, and soil 


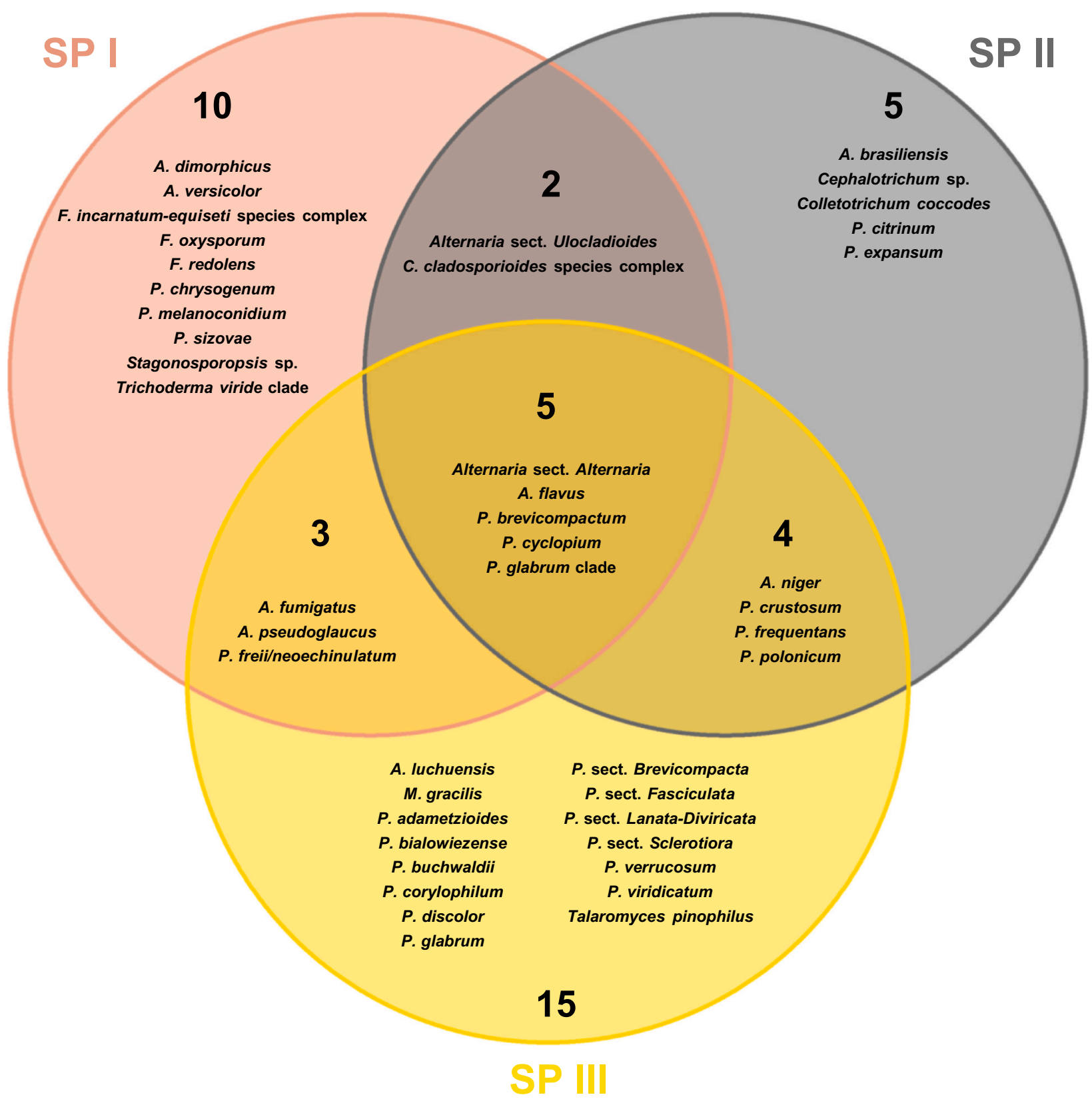

Fig. 4. Venn diagram showing diversity distribution of fungal species isolated from Chilean Capsicum annuum L. cv. "Cacho de Cabra" in the three sampling points considered (SP I, SP II and SP III).

(Decontardi et al., 2018; González et al., 2017; Garcia et al., 2018). As for the $P$. glabrum clade, our data corroborates Barreto et al. (2011) and Houbraken et al. (2014) that indicated high intra-specific $\beta$-tubulin variation for this group. Among the 21 strains grouped in this clade, only five could be identified as P. glabrum (1) and P. frequentans (4). The remaining lineages could represent putative new species (Supplementary Fig. 3), which is particularly interesting since these strains were isolated from dried pepper, an unusual substrate for this group. Similarly, $P$. cyclopium and $P$. polonicum are rarely isolated from chilli and its derivatives (Santos et al., 2011; Dashora and Sharma, 2018), possibly due to the shift in the conditions during the drying process causing that these airborne fungi seize to proliferate. Nevertheless, these two species were isolated here in more than one sampling point (Fig. 4) and at relatively high frequencies, particularly in sampling point III (Fig. 3). In fact, $P$. cyclopium, $P$. brevicompactum and $P$. glabrum clade were dominant in smoked C. annuum samples (SP III, Fig. 3) but they were isolated in all sampling points (Fig. 4), indicating that they might represent mycobiota residing in the plant that is very well adapted to shifts in abiotic conditions along the supply chain. Several other Penicillium species were found at lower frequencies. Some, such as $P$. expansum and $P$. citrinum, which are important and widespread postharvest pathogens that are highly adaptable to diverse environments (Pitt and Hocking, 2009; Prusky et al., 2014; Casquete et al., 2017). Others, such as $P$. corylophilum, $P$. verrucosum and $P$. viridicatum do well in storage conditions and have already been reported in dry foods, including chilli products (Bokhari, 2007; Hammami et al., 2014; Gherbawy et al., 2015; Garcia et al., 2018; Heperkan and Ermis, 2004; Jeswal and Kumar, 2015). Conversely, P. adametzioides, $P$. bialowiezense, $P$. buchwaldii, $P$. glabrum, and $P$. discolor, were isolated at low frequencies exclusively from smoked chilli (SP III, Figs. 3 and 4). From an ecological point of view, this represents important data since these strains are common spoilage fungi in other food matrices (e.g., cheese, nuts, and so forth), 
Table 2

Diversity measures estimated for a dataset of 192 strains isolated from Chilean Capsicum annuum L. cv. "Cacho de Cabra". Values were calculated for the overall dataset and for each sampling point individually (SP I, SP II and SP III).

\begin{tabular}{llllll}
\hline & $\mathrm{H}^{\prime}$ & $\mathrm{D}_{1}$ & $\mathrm{D}_{2}$ & $\mathrm{~S}$ & $\mathrm{E}$ \\
\cline { 2 - 6 } & $\begin{array}{l}\text { Shannon's } \\
\text { diversity }\end{array}$ & $\begin{array}{l}\text { Simpson's } \\
\text { diversity }\end{array}$ & $\begin{array}{l}\text { Simpson's } \\
\text { dominance }\end{array}$ & $\begin{array}{l}\text { Species } \\
\text { richness }\end{array}$ & $\begin{array}{l}\text { Simpson's } \\
\text { evenness }\end{array}$ \\
\hline Overall & 7.79589 & 0.94705 & 18.88525 & 44.00000 & 0.42921 \\
SP I & 4.91496 & 0.92278 & 12.94964 & 20.00000 & 0.64748 \\
SP II & 4.08746 & 0.89319 & 9.36283 & 16.00000 & 0.58518 \\
SP III & 5.47180 & 0.92564 & 13.44727 & 28.00000 & 0.48026 \\
\hline
\end{tabular}

but not in $C$. annuum pods.

Among Aspergillus, along with the less prevalent species mentioned above, the dominant ones were A. niger and A. flavus, particularly in SP II (Fig. 3). These species, among others belonging to sections Nigri and Flavi, have been shown to be predominant fungal contaminants in Capsicum pods and derivative products, being associated with the presence of mycotoxins in such food items (Chuaysrinule et al., 2020; Costa et al., 2019b; Frimpong et al., 2019; Ham et al., 2016).

This study also represents the first record, to the best of our knowledge, of A. luchuensis (1 strain in SP III) and P. melanoconidium (1 strain in SP I) isolated from C. annuum berry fruits.

\subsection{Diversity and sampling effort}

An array of diversity indices was estimated based on species counts for the complete 192 strains dataset (Table 2). Overall Shannon's diversity $\left(H^{\prime}\right)$, Simpson's diversity $\left(D_{1}\right)$ and Simpson's dominance $\left(D_{2}\right)$ values are high, indicating that the complete dataset is highly diverse, which is reflected on the species richness (S) value.

Higher values of $S$ can be indicative of the presence of several low frequency species (Morris et al., 2014). It is in accordance with the estimated overall Simpson's evenness (E) with a relatively low value showing that there are a few dominant species in the dataset (Morris et al., 2014). This is not unexpected due to the isolation scheme followed, i.e., as potentially mycotoxigenic genera were targeted during isolation, the final data set contains a higher number of Penicillium and Aspergillus isolates and species when comparing to other fungal groups. In fact, the directed isolation methodology used here hinders diversity estimates for individual sampling points (Table 2) by reducing the diversity estimates, particularly for SP I, due to the elimination of fastgrowing Mucorales species.

Chao1 richness estimates and observed rarefaction curves at several genetic distance levels were estimated for both analysed markers (Supplementary Fig. 4). For distance levels around 3\% or higher they tend to a stable value, particularly in the case of the estimated Chao1 curves (Supplementary Fig. 4A), meaning that the sequencing effort applied was near sufficient and the studied fungal community is relatively well characterized. Here, the lower observed OTU numbers (Supplementary Fig. 4B) in comparison with the estimated Chao1 are the result of the directed sampling strategy that was adopted in the present study. Several authors consider distance levels of $3 \%$ to represent species differentiation (Hamad et al., 2017; Passarini et al., 2013; Schloss and Handelsman, 2005; Siles and Margesin, 2016). As expected, the lineage-through-time plots show that the number of expected OTU's decreases with the increase of evolutionary distance (Supplementary Fig. 4C), which can be translated as each OTU corresponding to progressively higher taxonomic categories.

A similar approach to that described by Blaxter et al. (2005) was herein applied and a phylogenetic analysis of OTU consensus sequences and singletons was performed (Supplementary Fig. 5). The use of consensus sequences allowed to represent the diversity of the constituent sequences and further compare them with reference strains.
The obtained results show that threshold definition is most likely dependent of the studied taxonomic groups and species differentiation power of the analysed region. For the benA dataset, species at $0 \%$, sections at $6 \%$ and genus at $29 \%$ distance levels can be defined. On the other hand, the ITS dataset did not allow species classification of most isolates. However, it is possible to define groups (sections, species complexes or clades) at $0 \%$ distance levels and genus at $10 \%$.

From the results presented in this section it is possible to conclude that, despite some bias is introduced by the sampling scheme followed (presence of dominant species), we were able to recover low-frequency or rare species achieving a sound overview of the mycobiota present in Chilean C. annuum L. cv. "Cacho de Cabra", which is key information to improve risk assessment based on the presence of potential mycotoxigenic species.

\subsection{Mycotoxin detection and food safety considerations}

Small- and medium-scale pepper cultivation systems often do not have the same level of control as large-scale pepper producers, especially in relation to good handling and storage practices. In Chile, no data is available for on-field management systems of $C$. annuum L. cv. "Cacho de Cabra" production.

In our study, obtained fungal isolates were distributed per sampling point as follows: $31 \%$ from fresh (SP I; 60 isolates), $24 \%$ from dried (SP II; 46), and 45\% from smoked (SP III; 86) C. annuum samples. Possibly, in SP I, irrigation and fertiliser application above the recommended levels, as well as changes in climatic conditions, crop rotation, and soil texture, can enhance plant susceptibility to fungal colonization (Costa et al., 2019b). In the post-harvest phases (SP II and SP III), the control of temperature, humidity and $\mathrm{a}_{\mathrm{w}}$ are critical factors to guarantee a low bioburden. Despite no data is available for the specific production conditions used by each farmer, they all follow traditional methods during those production stages and, although reduction in moisture levels between sampling points is empirically observed, the percentage of fungal isolation increased. The obtained contamination profiles for each farmer are different (Fig. 5) and, given the use of similar techniques, major influencing points could be geographic location or the existence of specific mycobiomes installed in each production field. Other possible explanation includes the variation in environmental conditions to which chilli is exposed during the post-harvest stages, resulting in lower $\mathrm{a}_{\mathrm{w}}$ values and giving competitive advantage to xerophilic/xerotolerant fungi such Aspergillus and Penicillium species over other fungal species, ultimately leading to these genera representing a higher percentage of the fungal load (similar profile to that observed in Farmers I and VII, Fig. 5). Furthermore, the timeframe between drying and smoking might be variable and include changes in temperature, exposure to dust, wind and insect infestation, which can also contribute to the observed differences in fungal contamination profiles.

The high frequency of spoilage fungi isolated in all stages of production of $C$. annuum directly affects the quality of these pods that are consumed fresh and may also compromise the quality of derived products. In Chile, OTA has been detected above the limits established by Chilean and European Commission regulations in Capsicum and Merkén samples (ACHIPIA, 2018). Ikoma et al. (2015) evaluated chilli samples produced and marketed in Chile and detected OTA in assessed samples in very high concentration levels. In fact, geographical and climatic characteristics, and crop management systems (poor hygienic conditions, oscillation in water activity and temperature) can favour increased mycological loads having a direct effect on mycotoxin contamination levels. In addition, $\mathrm{NaCl}$ and capsaicinoids compounds have been referred as acting as external signals to trigger OTA biosynthesis in this type of substrate (Costa et al., 2019b; Stoll et al., 2013).

The OTA-producing species with greatest relevance are $A$. carbonarius, A. niger, A. ochraceus, $P$. nordicum, and $P$. verrucosum (Cabañes et al., 2010; Cabañes and Bragulat, 2018). In our study, all strains of Penicillium (113) and Aspergillus (35) isolated were subjected to OTA 


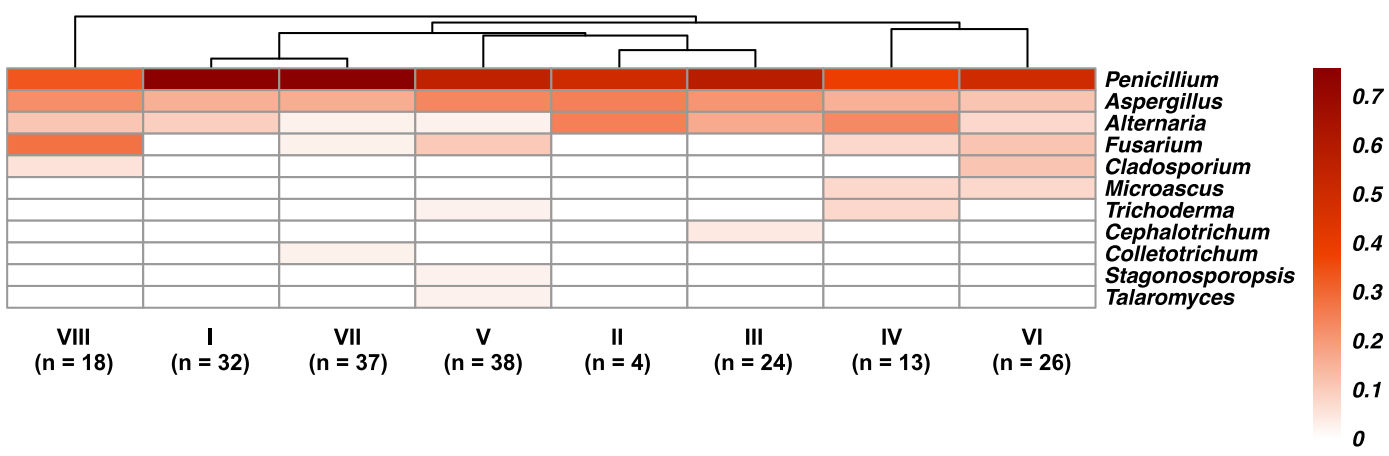

Fig. 5. Heat map showing genus relative abundance distributed by the eight Farmers considered (I-VIII). Numbers in between parenthesis represent the number of isolates originating from each farmer. Sites were clustered using UPGMA dendogram based on Bray-Curtis similarities. Colour legend and scale provided in the figure. (For interpretation of the references to colour in this figure legend, the reader is referred to the web version of this article.)

production analysis. Obtained data showed that, under the growth conditions used (see Section 2.6), none of the strains was able to produce OTA above the detection limits. OTA production varies not only due to the environmental conditions but is also species and strain dependable. A. carbonarius can take only 5 days to reach the highest production, A. niger may take 7 days (Zeilinger et al., 2014) and A. westerdijikae 10 days (Vipotnik et al., 2017), for instance. Due to the different isolates included in this study, 7 days growth for OTA analysis represented a compromise between the different species tested. The same was applied to the growth temperature used for the analyses. Here, 14 strains of $A$. niger were isolated. Although A. niger is reported as OTA producer, relatively few strains (c.a. 10\%) can biosynthesise this mycotoxin (Hocking et al., 2007). Furthermore, 1 P. verrucosum strain was isolated from smoked pepper (SP III). This strain was positive for otanpsPN gene (unpublished data), however it did not produce detectable levels of OTA in synthetic medium. The otanpsPN gene is key in OTA biosynthesis as it is involved in the linkage of the phenylalanine moiety to the polyketide. Despite the presence of otanpsPN, other genes or gene regulators are essential for the OTA biosynthetic pathway (Gallo et al., 2012).

The absence of OTA-producing fungi does not guarantee that the $C$. annuum samples are OTA free. Once secreted, OTA remains in the commodity even after the disappearance of the fungal contaminants. Manual sorting of the damaged fruits by farmers can help reducing the mycotoxin levels, however, OTA is a reasonably heat stable molecule that can persist through most food processing operations (Duarte et al., 2010; Karlovsky et al., 2016). Furthermore, as mentioned previously, mycotoxin production and secretion are closely associated with the nutritional components of the substrate (Abbas et al., 2009). Some studies emphasize the effect of carotenoids and other pungent substances present in $C$. annuum pod in the growth rates and mycotoxin expression of some fungal species (Masood et al., 1994; Norton, 1997; Santos et al., 2010). For this, additional analyses should be made directly on the fruits of $C$. annuum.

Furthermore, our study has detected other potentially mycotoxigenic strains such as A. flavus (e.g., aflatoxins), Alternaria sect. Alternaria (e.g., alternariol), P. cyclopium (e.g., penicillic acid), P. citrinum (e.g., citrinin), P. expansum (e.g., citrinin, patulin), A. fumigatus (e.g., gliotoxin), P. polonicum (e.g., cyclopiazonic acid and penicillic acid) and $F$. oxysporum (e.g., fusarins and moniliformin) were isolated. The co-occurrence of mycotoxins has already been reported in chilli products (Costa et al., 2019b; Perrone and Susca, 2017; Pitt and Hocking, 2009).

From the point of view of food safety, isolation in all sampling points of potentially mycotoxigenic strains highlights the importance of improving bioburden control. A good adaptation of these strains to different conditions along the production chain of $C$. annuum, can be a threat, since the drying and smoking processes can be barriers to the development of fungi, but they do not affect the mycotoxins already released in the food matrix during previous stages of the food production chain.

\section{Conclusion}

This study provides the first comprehensive dataset regarding mycobiota, particularly that with mycotoxigenic potential, of chilli $C$. annuum L. cv. "Cacho de Cabra". Our results clearly show that fresh, dried and smoked chilli pod are substrates increasingly selective for occurrence of potentially mycotoxigenic fungi. Under post-harvest conditions, Aspergillus and Penicillium species proliferated replacing the higher levels of Alternaria and Fusarium observed at harvest time. This shift in the fungal community of $C$. annuum L. cv. "Cacho de Cabra" is the result of differences in the ecophysiological conditions in the field and the post-harvest phases. The decrease in $\mathrm{a}_{\mathrm{w}}$ during the drying and smoking processes was not sufficient to avoid fungal growth. In addition, the exposure timeframe of chilli pods to inadequate conditions throughout the drying and smoking processes may have favoured fungal growth in the samples. Species of Penicillium and Aspergillus, including potential toxigenic ones, were isolated in the three sampling time points. The most abundant strains were $P$. brevicompactum and $P$. crustosum. Among Aspergillus species, A. niger and A. flavus were dominant.

Isolated Penicillium and Aspergillus species did not produced OTA above the detection limits considering the used in vitro conditions. Nevertheless, several of the isolated fungal species can decay Capsicum pods and have the potential to produce other mycotoxins. Therefore, the mycobiota present in C. annuum L. cv. "Cacho de Cabra" poses both a quality risk with the potential to originate economic losses but also a health risk due to the possible mycotoxin contamination of the fresh pods or derived products. Thus, it is highly advisable to improve control measures during $C$. annuum production and storage chain in order to reduce the presence of mycological contamination. Considering food security, further studies are needed to clarify whether the mycobiota isolated from the $C$. annuum cv. "Cacho de Cabra" berry fruits is able of producing other mycotoxins.

Supplementary data to this article can be found online at https:// doi.org/10.1016/j.ijfoodmicro.2020.108833.

\section{Declaration of competing interest}

The authors declare no conflict of interest.

\section{Acknowledgments}

The Authors are thankful to The Mapuche Communities of the Region of La Araucanía (Chile), involved in this study, for its contribution and commitment to improving the sanitary quality of berry fruits and Merkén; and for supplying berry fruits and Merkén samples for 
this study: Chaltu mai. The Authors also thank to Miss Natalia Castillo (Chilean Social Worker) for her indefatigable support, sympathy and dynamism involving the contact with local communities, based on an intercultural approach and a deep respect for the Mapuche worldview.

\section{Funding}

J.C. thanks to CONICYT/Chile for her Ph.D. grant no 21181445. R.R thanks to CONICYT/Chile for his MSc. grant Folio $\mathrm{N}^{\circ}$ 7317076, Application $\mathrm{N}^{\circ} 73170764$. The present work was partially funded by the Universidad de La Frontera (Temuco, Chile) through the Project DIUFRO PIA19-0001. Moreover, this study was also supported by the Portuguese Foundation for Science and Technology (FCT) under the scope of the strategic funding of UID/BIO/04469/2019 unit and BioTecNorte operation (NORTE-01-0145-FEDER-000004) funded by the European Regional Development Fund under the scope of Norte2020 - Programa Operacional Regional do Norte.

\section{References}

Abbas, A., Valez, H., Dobson, A.D.W., 2009. Analysis of the effect of nutritional factors on OTA and OTB biosynthesis and polyketide synthase gene expression in Aspergillus ochraceus. Int. J. Food Microbiol. 135, 22-27. https://doi.org/10.1016/j.ijfoodmicro. 2009.07.014.

Abrunhosa, L., Ines, A., Rodrigues, A.I., Guimaraes, A., Pereira, V.L., Parpot, P., Mendes Faia, A., Venâncio, A., 2014. Biodegradation of ochratoxin A by Pediococcus parvulus isolated from Douro wines. Int. J. Food Microbiol. 188, 45-52. https://doi.org/10. 1016/j.ijfoodmicro.2014.07.019.

Adebanjo, A., Shopeju, E., 1993. Sources and mycoflora associated with some sundried vegetables in storage. Int. Biodeterior. Biodegradation. 4, 255-263. https://doi.org/ 10.1016/0964-83059390021-S.

Agencia Chilena para la Calidad e Inocuidad Alimentaria (ACHIPIA), 2018. Ocratoxina A en ají y merkén, Chile. Perfil de Riesgo/ACHIPIA N ${ }^{\circ} 02 / 2018$ version No1. Available in. https://www achipia.gob.cl/wp-content/uploads/2018/06/Perfil-deRiesgoOcratoxina-en-aji merk-n-v1-2018-1.pdf access on 17/07/2018.

Ahn, J., Kim, D., Jang, H.S., Kim, Y., Shim, W.B., Chung, D.H., 2010. Occurrence of ochratoxin A in Korean red paprika and factors to be considered in prevention strategy. Mycotoxin Res. 4, 279-286. https://doi.org/10.1007/s12550-010-0067-2.

Almela, L., Rabe, V., Sánchez, T.F., López-Pérez, J.P., Gabaldón, J.A., Guardiola, L., 2007. Ochratoxin A in red paprika: relationship with the origin of the raw material. Int. J. Food. Microbiol. 24, 319-327. https://doi.org/10.1016/j.fm.2006.08.001.

Atanda, O.O., Akano, D.A., Afolabi, J.F., 1990. Mycoflora of dry "tatase" pepper (Capsicum annuum L.) stored for sale in Ibadan markets. Lett. Appl. Microbiol. 10, 35-37. https://doi.org/10.1111/j.1472-765X.1990.tb00089.x.

Barreto, M.C., Houbraken, J., Samson, R.A., Frisvad, J.C., San-Romão, M.V., 2011. Taxonomic studies of the Penicillium glabrum complex and the description of a new species P. subericola. Fungal Divers 49, 23-33. https://doi.org/10.1007/s13225-0110090-4.

Blaxter, M., Mann, J., Chapman, T., Thomas, F., Whitton, C., Floyd, R., Abebe, E., 2005. Defining operational taxonomic units using DNA barcode data. Philos. Trans. R. Soc. Lond. Ser. B Biol. Sci. 360 (1462), 1935-1943.

Bokhari, F.M., 2007. Spices mycobiota and mycotoxins available in Saudi Arabia and their abilities to inhibit growth of some toxigenic fungi. Mycobiol. 35, 47-53. https:// doi.org/10.4489/myco.2007.35.2.047.

Bragulat, M.R., Abarca, M.L., Cabanes, F.J., 2001. An easy screening method for fungi producing ochratoxin A in pure culture. Int. J. Food Microbiol. 71, 139-144. https:// doi.org/10.1016/S0168-1605(01)00581-5.

Cabañes, F.J., Bragulat, M.R., 2018. Black aspergilli and ochratoxin A-producing species in foods. Curr. Opin. Food Sci. 23, 1-10. https://doi.org/10.1016/j.cofs.2018.01.006.

Cabañes, F.J., Bragulat, M.R., Castellá, G., 2010. Ochratoxin A producing species in the genus Penicillium. Toxins 2, 1111-1120. https://doi.org/10.3390/toxins2051111.

Casquete, R., Rodríguez, A., Hernández, A., Martín, A., Bartolomé, T., Córdoba, J.J., Córdoba, M.G., 2017. Occurrence of toxigenic fungi and mycotoxins during smoked paprika production. J. Food Prot. 80, 2068-2077. https://doi.org/10.4315/0362 028X.JFP-17-164.

Chen, H., 2018. VennDiagram: generate high-resolution Venn and Euler plots. R package version 1.6.20. https://CRAN.R-project.org/package = VennDiagram.

Chuaysrinule, C., Maneeboon, T., Roopkham, C., Mahakarnchanakul, W., 2020. Occurrence of aflatoxin- and ochratoxin A-producing Aspergillus species in Thai dried chilli. J. Agric. Food Res. 2. https://doi.org/10.1016/j.jafr.2020.100054.

Costa, J., Lima, N., Santos, C., 2019a. Chilean pepper: spoilage fungi and mycotoxins contamination risk in Capsicum products. In: Oliveira, L. A, Jesus, M. A., Jackisch Matsuura, A.B., Oliveira, J.G.S., Gasparotto, L., Lima-Neto, R.G., Rocha, L.C. (Eds.), Conhecimento, conservação e uso de fungos. INPA Publishing, Manaus, pp. 29-40.

Costa, J., Rodríguez, R., Garcia-Cela, E., Medina, A., Magan, N., Lima, N., Battilani, P. Santos, C., 2019b. Overview of fungi and mycotoxin contamination in Capsicum pepper and in its derivatives. Toxins 11,1-16. https://doi.org/10.3390/ toxins11010027.

da Cruz Cabral, L., Terminiello, L., Pinto, V.F., Nielsen, K.F., Patriarca, A., 2016. Natural occurrence of mycotoxins and toxigenic capacity of Alternaria strains from mouldy peppers. Int. J. Food Microbiol. 236, 155-160. https://doi.org/10.1016/j. ijfoodmicro.2016.08.005.

Dashora, A., Sharma, K., 2018. Isolation of fungal species from infected chilli fruit and their identification. W.J.P.R. 7, 1146-1159. https://doi.org/10.20959/wjpps2018812159 .

Decontardi, S., Soares, C., Lima, N., Battilani, P., 2018. Polyphasic identification of Penicillia and Aspergilli isolated from Italian grana cheese. Food Microbiol. 73, 137-149. https://doi.org/10.1016/j.fm.2018.01.012.

Duarte, S.C., Pena, A., Lino, C.M., 2010. A review on ochratoxin A occurrence and effects of processing of cereal and cereal derived food products. Food Microbiol. 27, 187-198. https://doi.org/10.1016/j.fm.2009.11.016.

Esteban, A., Abarca, M.L., Bragulat, M.R., Cabañes, F.I., 2006. Study of the effect of water activity and temperature on ochratoxin A production by Aspergillus carbonarius. Food Microbiol. 23, 634-640. https://doi.org/10.1016/j.fm.2005.12.006.

Foerster, C., Muñoz, K., Delgado-Rivera, L., Rivera, A., Cortés, S., Müller, A., Arriagada G., Ferreccio, C., Rios, G., 2020. Occurrence of relevant mycotoxins in food commodities consumed in Chile. Mycotoxin Res. 36, 63-72. https://doi.org/10.1007/ s12550-019-00369-5.

Food and Agriculture Organization of the United Nations (FAOSTAT), 2018. Available online: http://faostat.fao.org/site/567/default aspx\#ancor accessed on 5 April 2018.

Frimpong, G.K., Adekunle, A.A., Ogundipe, O.T., Solanki, M.K., Sadhasivam, S., 2019. Identification and toxigenic potential of fungi isolated from Capsicum peppers. Microorganisms 7, 1-10. https://doi.org/10.3390/microorganisms7090303.

Frisvad, J.C., Filtenborg, O., 1983. Classification of terverticillate Penicillia based on profiles of mycotoxins and other secondary metabolites. Appl. Environ. Microbiol. 46, 1301-1310.

Fundación para la Innovación Agraria (FIA), 2006. Estudio de mercado nacional e internacional de Aji-Merkén. In: Proyecto de innovación en región de La Araucanía, pp. $1-77$.

Fundación para la Innovación Agraria (FIA), 2010. Resultados y Lecciones en ají Merkén con alto valor Agregado. pp. 1-66.

Gallo, A., Bruno, K.S., Solfrizzo, M., Perrone, G., Visconti, A., Baker, S.E., 2012. New Insight into the Ochratoxin A Biosynthetic Pathway Through Deletion of a Nonribosomal Peptide Synthetase Gene in Aspergillus carbonarius 78, 8208-8218. DOI. https://doi.org/10.1128/AEM.02508-12.

Garampalli, R.H., Gapalkrishna, M.K., Li, H., Brewer, M.T., 2016. Two Stagonosporopsis species identified as causal agents of gummy stem blight epidemics of gherkin cucumber (Cucumis sativus) in Karnataka, India. Eur. J. Plant. Pathol. 145, 507-512. https://doi.org/10.1007/s10658-015-0841-2.

Garcia, M.V., Parussolo, G., Moro, C.B., Bernardi, A.O., Copetti, M.V., 2018. Fungi in spices and mycotoxigenic potential of some Aspergilli isolated. Food. Microbiol. 73, 93-98. https://doi.org/10.1016/j.fm.2018.01.013.

Gherbawy, Y.A., Shebany, Y.M., Hussein, M.A., Maghraby, T.A., 2015. Molecular detection of mycobiota and aflatoxin contamination of chili. Arch. of Biol. Sci. 1, 223-234. https://doi.org/10.2298/ABS141010028G.

Glass, L., Donaldson, G.C., 1995. Development of primer sets designed for use with the PCR to amplify conserved genes from filamentous ascomycetes. Appl. Environ. Microbiol. 61, 1323-1330.

González, M.G.M., Romero, S.M., Arjona, M., Larumbe, A.G., Vaamonde, G., 2017. Microbiological quality of Argentinian paprika. Rev. Argent. Microbiol. 49, 339-346. https://doi.org/10.1016/j.ram.2017.02.006.

Govindarajan, V.S., Salzer, U.J., 1985. Capsicum-production, technology, chemistry, and quality part 1 : history, botany, cultivation, and primary processing. Crit. Rev. Food Sci. Nutr. 22, 109-176. https://doi.org/10.1080/10408398509527412.

Haapalainena, M., Latvalab, S., Kuivainena, E., Oiua, Y., Segerstedtb, M., Hannukkala, A.O., 2016. Fusarium oxysporum, F. proliferatum and F. redolens associated with basal rot of onion in Finland. Plant Pathol. 65, 1310-1320.

Ham, H., Kim, S., Kim, M.H., Lee, S., Hong, S.K., Ryu, J.G., Lee, T., 2016. Mycobiota of ground red pepper and their aflatoxigenic potential. J. Microbiol. 54, 832-837. https://doi.org/10.1007/s12275-016-6480-2.

Hamad, I., Ranque, S., Azhar, E.I., Yasir, M., Jiman-Fatani, A.A., Tissot-Dupont, H., Raoult, D., Bittar, F., 2017. Culturomics and amplicon-based metagenomic approaches for the study of fungal population in human gut microbiota. Sci. Rep. 7 (1), 16788. https://doi.org/10.1038/s41598-017-17132-4.

Hammami, W., Fiori, S., Al Thani, R., Kali, N.A., Balmas, V., Migheli, Q., Jaoua, S. 2014 Fungal and aflatoxin contamination of marketed spices. Food Control. 37, 177-181. https://doi.org/10.1016/j.foodcont.2013.09.027.

Haruna, M., Dangora, D.B., Khan, A.U., Batagarawa, U.S., Ibrahim, H., Adamu, S., 2017. Incidence of fungal flora and aflatoxin in some spices sold in central market, Funtua, Nigeria. UMYU J. Microbiol. Res. 2, 1-7.

Heperkan, D., Ermis, Ö.C., 2004. Mycotoxins in spices: red pepper. In: Barug, D., Egmond, H.P., López-García, R., Osenbruggen, W.A., Visconti, A. (Eds.), Meeting the Mycotoxin Menace. Wageningen Academic Publishers, Wageningen, pp. 197-219.

Hocking, A.D., Su-lin, L.L., Kazi, B.A., Emmett, R.W., Scott, E.S., 2007. Fungi and mycotoxins in vineyards and grape products. Int. J. Food Microbiol. 119, 84-88. https:// doi.org/10.1016/j.ijfoodmicro.2007.07.031.

Houbraken, J.A.M.P., Frisvad, J.C., Samson, R.A., 2010. Taxonomy of Penicillium citrinum and related species. Fungal Divers 44, 117-133. https://doi.org/10.1007/s13225010-0047-z.

Houbraken, J., Visagie, C.M., Meijer, M., Frisvad, J.C., Busby, P.E., Pitt, J.I., Seifert, K.A., Louis-Seize, G., Demirel, R., Yilmaz, N., Jacobs, K., Christensen, M., Samson, R.A., 2014. A taxonomic and phylogenetic revision of Penicillium section Aspergilloides. Stud. Mycol. 78, 373-451. https://doi.org/10.1016/j.simyco. 2014.09.002.

Ikoma, T., Tsuchiya, Y., Asai, T., Okano, K., Endoh, K., Yamamoto, M., Nakamura, K., 2015. Ochratoxin contamination of red chili peppers from Chile, Bolivia and Peru showing high incidences of gallbladder cancer. Asian Pac. J. Cancer Prev. 16, 
5897-5991. https://doi.org/10.7314/APJCP.2015.16.14.5987.

Iqbal, Q., Amjad, M., Asi, M.R., Arin, A., 2011. Assessment of hot peppers for aflatoxin and mold proliferate during storage. J. Food Prot. 74, 830-835. https://doi.org/10 4315/0362-028X.JFP-10-449.

Jeswal, P., Kumar, D., 2015. Mycobiota and natural incidence of aflatoxins, ochratoxin A, and citrinin in Indian spices confirmed by LC-MS/MS. Int. J. Food Microbiol. 3, 1-8. https://doi.org/10.1155/2015/242486.

Karlovsky, P., Suman, M., Berthiller, F., Meester, J., Eisenbrand, G., Perrin, I., Oswald, I.P., Speijers, G., Chiodini, A., Recker, T., Dussort, P., 2016. Impact of food processing and detoxification treatments on mycotoxin contamination. Mycotoxin Res. 32, 179-205. https://doi.org/10.1007/s12550-016-0257-7.

Kimura, M., 1980. A simple method for estimating evolutionary rate of base substitutions through comparative studies of nucleotide sequences. J. Mol. Evol. 16, 111-120. https://doi.org/10.1007/bf01731581.

Klich, M.A., 2002. Identification of Common Aspergillus Species. CBS, Utrecht, the Netherlands.

Kolde, R., 2018. pheatmap: pretty heatmaps. R package version 1.0.10. https://CRAN.Rproject.org $/$ package $=$ pheatmap.

Kumar, S., Stecher, G., Tamura, K., 2016. MEGA7: molecular evolutionary genetics analysis version 7.0 for bigger datasets. Mol. Biol. Evol. 33, 1870-1874. https://doi. org/10.1093/molbev/msw054.

Masood, A., Dogra, J.V.V., Jha, A.K., 1994. The influence of colouring and pungent agents of red Chilli (Capsicum annum) on growth and aflatoxin production by Aspergillus flavus. Lett. Appl. Microbiol. 18, 184-186. https://doi.org/10.1111/j.1472-765X. 1994.tb00841.x.

McCune, B., Grace, J.B., 2002. Analysis of Ecological Communities. MjM Software Design, Gleneden Beach, Oregon.

Meteochile, 2020. Dirección Meteorológica de Chile. Access: http://www.meteochile. gob.cl/ Accessed at 06/06/2020.

Morris, E.K., Caruso, T., Buscot, F., Fischer, M., Hancock, C., Maier, T.S., Meiners, T., Müller, C., Obermaier, E., Prati, D., Socher, S.A., Sonnemann, I., Wäschke, N., Wubet, T., Wurst, S., Rillig, M.C., 2014. Choosing and using diversity indices: insights for ecological applications from the German Biodiversity Exploratories. Ecol. Evol. 4, 3514-3524. https://doi.org/10.1002/ece3.1155.

Nelson, P.E., Toussoun, T.A., Marasas, W.F.O., 1983. Fusarium Species: An Illustrated Manual for Identification. The Pennsylvania State University Press, University Park and London, UK.

Norton, R.A., 1997. Effect of carotenoids on aflatoxins B1 synthesis by Aspergillus flavus. Phytopathology 87, 814-821. https://doi.org/10.1094/PHYTO.1997.87.8.814.

Oksanen, J., Blanchet, F.G., Friendly, M., Kindt, R., Legendre, P., McGlinn, D., Minchin, P.R., O'Hara, R.B., Simpson, G.L., Solymos, P., Stevens, M.H.H., Szoecs, E., Wagner, H., 2018. Vegan: community ecology package. R package version 2.5-2. https:// CRAN.R-project.org/package = vegan.

Passarini, M.R., Santos, C., Lima, N., Berlinck, R.G., Sette, L.D., 2013. Filamentous fungi from the Atlantic marine sponge Dragmacidon reticulatum. Arch Microbiol. 195 (2), 99-111. https://doi.org/10.1007/s00203-012-0854-6.

Perrone, G., Susca, A., 2017. Penicillium species and their associated mycotoxins. In: Moretti, A., Susca, A. (Eds.), Mycotoxigenic Fungi. Methods in Molecular Biology, Humana Press, New York, NY, https://doi.org/10.1007/978-1-4939-6707-0_5. DOI

Pitt, J.I., Hocking, A.D., 2009. Spoilage of stored, processed and preserved foods. In: Pitt, J.I., Hocking, A.D. (Eds.), Fungi and Food Spoilage. Springer, Boston, MA. https:// doi.org/10.1007/978-0-387-92207-2 12.

Prusky, D., Alkan, N., Miyara, I., Barad, S., Davidzon, M., Kobiler, I., Brown-Horowitz, S., Lichter, A., Sherman, A., Fluhr, R., 2014. Mechanisms modulating postharvest pathogen colonization of decaying fruits. In: Prusky, D., Gullino, M.L. (Eds.), Postharvest Pathology. Springer, Netherlands, pp. 43-55.

R Environment, 2020. Team R: a language and environment for statistical computing. In: R Foundation for Statistical Computing 2016. Austria, Vienna Available from: http:// www.R-project.org/ Version 3.5.1.

Robert, C., 2004. MUSCLE: multiple sequence alignment with high accuracy and high throughput. Nucleic Acids Res. 32, 1792-1797. https://doi.org/10.1093/nar/ gkh340.

Rodrigues, P., Venâncio, A., Kozakiewicz, Z., Lima, N., 2009. A polyphasic approach to the identification of aflatoxigenic and non-aflatoxigenic strains of Aspergillus section Flavi isolated from Portuguese almonds. Int. J. Food Microbiol. 129, 187-193. https://doi.org/10.1016/j.ijfoodmicro.2008.11.023.

RStudio, 2016. RStudio: Integrated Development for R. RStudio, Inc., Boston, MA URL. http://www.rstudio.com/ version 1.1.453.

Ruiz-Moyano, S., Benito, J., Martı, A., Aranda, E., Herna, A, 2009. Characterization of molds isolated from smoked paprika by PCR-RFLP and micellar electrokinetic capillary electrophoresis. Food Microbiol. 26, 776-782. https://doi.org/10.1016/j.fm. 2009.05.002.

Samson, R.A., Hockstra, E.S., Frisvad, J.C., Filtenborg, O., 2000. Introduction to food and airborne Fungi. In: Wageningen, the Netherlands: Centaalbureau Voorschimmelculturs-Utrecht Ponson and Looyen. Press, Wageningen.

Samson, R.A., Visagie, C.M., Houbraken, J., Hong, S.-B., Hubka, V., Klaassen, C.H.W. Perrone, G., Seifert, K.A., Susca, A., Tanney, J.B., Varga, J., Kocsubé, S., Szigeti, G., Yaguchi, T., Frisvad, J.C., 2014. Phylogeny, identification and nomenclature of the genus Aspergillus. Stud. Mycol. 7, 141-173. https://doi.org/10.1016/j.simyco.2014. 07.004.

Sanchis, V., Magan, N., 2004. Environmental conditions affecting mycotoxins. In: Magan, N., Olsen, M. (Eds.), Mycotoxins in Food: Detection and Control. Woodhead Publishing, Cambridge, 9781855739086, pp. 174-189.

Santos, L., Kasper, R., Gil-Serna, J., Marín, S., Sanchis, V., Ramos, A.J., 2010. Effect of Capsicum carotenoids on growth and ochratoxin A production by chilli and paprika Aspergillus spp. isolates. Int. J. Food Microbiol. 142, 354-359. https://doi.org/10. 1016/j.ijfoodmicro.2010.07.018.

Santos, L., Marín, S., Mateo, E.M., Gil-Serna, J., Valle-Algarra, F.M., Patiño, B., Ramos, A.J., 2011. Mycobiota and co-occurrence of mycotoxins in Capsicum powder. Int. J. Food Microbiol. 3, 270-276. https://doi.org/10.1016/j.ijfoodmicro.2011.09.011.

Sanzani, S.M., Reverberi, M., Geisen, R., 2016. Mycotoxins in harvested fruits and vegetables: insights in producing fungi, biological role, conducive conditions, and tools to manage postharvest contamination. Postharvest Biol. Technol. 122, 95-105. https://doi.org/10.1016/j.postharvbio. 2016.07.003.

Schloss, P., Handelsman, J., 2005. Introducing DOTUR, a computer program for defining operational taxonomic units and estimating species richness. Appl. Environ. Microbiol. 71. https://doi.org/10.1128/AEM.71.3.1501-1506.2005.

Schoch, C.L., Seifert, K.A., Huhndorf, S., Robert, V., Spouge, J.L., Levesque, C.A., Chen, W., Fungal Barcoding Consortium, 2012. Nuclear ribosomal internal transcribed spacer (ITS) region as a universal DNA barcode marker for fungi. PNAS 109 (16), 6241-6246. https://doi.org/10.1073/pnas.1117018109.

Shannon, C., 1948. A mathematical theory of communication. Bell Syst. Tech. J. 27 (379-423), 623-656.

Siles, J.A., Margesin, R., 2016. Abundance and diversity of bacterial, archaeal, and fungal communities along an altitudinal gradient in Alpine forest soils: what are the driving factors? Microb. Ecol. 72, 207-220. https://doi.org/10.1007/s00248-016-0748-2.

Simpson, E.H., 1949. Measurement of diversity. Nature 163, 688.

Stoll, D., Schmidt-Heydt, M., Geisen, R., 2013. Differences in the regulation of Ochratoxin A by HOG pathway in Penicillium and Aspergillus in response to high osmolar environments. Toxins 5 (7), 1282-1298. https://doi.org/10.3390/toxins5071282.

Tamura, K., Nei, M., 1993. Estimation of the number of nucleotide substitutions in the control region of mitochondrial DNA in humans and chimpanzees. Mol. Biol. Evol. 10, 512-526. https://doi.org/10.1093/oxfordjournals.molbev.a040023.

Tančinová, D., Mokrỳ, M., Barboráková, Z., Mašková, Z., 2014. Mycobiota of spices and aromatic herbs. Potravinarstvo 1, 172-177. https://doi.org/10.5219/375.

Taverniers, I., De Loose, M., Van Bockstaele, E., 2004. Trends in quality in the analytical laboratory. II. Analytical method validation and quality assurance. Trends Anal. Chem. 23, 535-552. https://doi.org/10.1016/j.trac.2004.04.001.

Vipotnik, Z., Rodríguez, A., Rodrigues, P., 2017. Aspergillus westerdijkiae as a major ochratoxin A risk in dry-cured ham based-media. Int. J. Food Microbiol. 241, 244-251. https://doi.org/10.1016/j.ijfoodmicro.2016.10.031.

Visagie, C.M., Houbraken, J., Frisvad, J.C., Hong, S.-B., Klaassen, C.H.W., Perrone, G., Seifert, K.A., Varga, J., Yaguchi, T., Samson, R.A., 2014. Identification and nomenclature of the genus Penicillium. Stud. Mycol. 78, 343-371. https://doi.org/10.1016/ j.simyco.2014.09.001.

White, T.J., Burns, T., Lee, S., Taylor, J.W., 1990. Amplification and direct sequencing of fungal ribosomal RNA genes for phylogenetics. In: Gelgard, D.H., Sninsky, J.J., White, T.J. (Eds.), PCR Protocols: Innis, M.A. Academic Press, New York, A Guide to Methods and Applications, pp. 315-322.

Whittaker, R.H., 1972. Evolution and measurement of species diversity. Taxon 21, 213-251.

Zeilinger, S., Martín, J.F., García-Estrada, C., 2014. Biosynthesis and Molecular Genetics of Fungal Secondary Metabolites. pp. 129-135. https://doi.org/10.1007/978-1. 4939-1191-2. 